Crossroads 5/2015, pp. 16-31

Binayak Roy

K.G.T. Mahavidyalaya, Bagdogra

\title{
Mapping the Transnation: Amitav Ghosh's The Shadow Lines
}

\begin{abstract}
Central to Ghosh's oeuvre is the idea that the nation is a fiction whose boundaries are continuously being reimagined and redrawn. Nationalism creates binary divisions, and projects a kind of "false" history which would buttress its own interest. The ideology of modernity and its various avatars, like Western geographical and ideological expansionism, modernist knowledge production strategies, and racism, create a Manichaean dialectic between the self and its other. Ghosh's engagement with the frequency of boundary-crossings within and outside India, challenges the essentialist definitions of nations and societies. Ghosh's endorsement of the syncretism and humanism that downplay cultural differences explains his antipathy towards nationalism and its divisive epistemology. Despite his celebration of cultural pluralism, an acute sense of the sameness of man across "looking glass borders" and temporal divides underlies his work. Questioning the authoritarian and coercive actions of the postcolonial nation state, Ghosh pines for the Nehruvian utopia of a secularist, democratic national unity which assimilates Indian diversity in a syncretic whole. Based on an ethically conceived solidarity, this feeling of communitarianism would provide an ideal alternative to religious and ethnic chauvinism and "Majoritarianism", as well as political dispersal and the religious/ethnic violence rampant in contemporary Hindu nationalism. Ghosh distrusts the nationalist political and official discourse of a faceless and dehumanizing statist machinery detached from the actual lives of people. In The Shadow Lines, Ghosh thematizes the migrations of people(s), the importance of connections between the past and the present, the changing status of nation-states, the fluid nature of boundaries, intercultural communication beyond nationalism, the spread of Western modes of production, and encounters between different cultures - all of which are the fallout of globalization.
\end{abstract}

Keywords: cosmopolitanism, the transnation, space, alterity, selfhood.

"After all, in the thousands of years of Indian history, there never was such a creature as a united India. Nobody ever managed to rule the whole place, not the Mughals, not the British. And then, that midnight, the thing that had never existed was suddenly 'free'. But what on earth was it? On what common ground (if any) did it, does it, stand?" - Salman Rushdie, Imaginary Homelands.

"We live in a world of imagined communities. We are also policed through a world of fixed state borders. Accustomed as we are to the fluidity of our own imaginations, we are also, increasingly, being accustomed to negotiating borders, and using the one to serve the other." - Abena Busia, ALA Bulletin .

"Writing has nothing to do with signifying. It has to do with surveying, mapping, even realms that are yet to come." - Deleuze and Guattari, A Thousand Plateaus.

\section{[I]}

The idea of the autonomous nation-state enclosed within non-permeable borders has generated universalist notions of ethnic homogeneity, linguistic uniformity, moral absolutism, and cultural consonance, as the markers of nationhood. When this totalizing norm was filtered through Enlightenment ideals, it powerfully inflected Eurocentric ideas of the self, and 
simultaneously constructed the non-European Other. The nation is an "unprecedented" institution, contends Sudipta Kaviraj, which attempts to replace premodern communities, marked by "fuzzy" boundaries and intense emotional ties with an "enumerated" and modern national community. The latter is territorially specific, has clear boundaries and must "enumerate" what belongs to it. Hence, "the endless counting of citizens, territories, resources, majorities, minorities, institutions, activities, import, export, incomes, projects, births, deaths, diseases" (1992: 30-31). Benedict Anderson defines the nation as "an imagined political community - and imagined as both inherently limited and sovereign" (1983: 15). It is imagined by its people and ideologues, imaginings fraught with incongruities. One of these is that nation-states, although historically "new" entities, "always loom out of an immemorial past" (1983: 19) as the same entity of a united people sharing the same heritage. Modern India needs to be judged from this perspective. The Indian nation is "not an object of discovery but of invention" (Kaviraj 1992: 1).

Colonialism in India created a rupture out of which the nation emerged as an entirely new historical institution. Colonial borders were drawn up without any knowledge of the peoples or cultures whose lives they affected. Not only did this sometimes result in people with little historical connection being thrown together, it also often resulted in communities being torn apart, internally divided on the basis of administrative fiat. Pertinent here is Arundhati Roy's (2002) observation that "India, as a modern nation state, was marked out with precise geographical boundaries by a British Act of Parliament in 1899. Our country, as we know it, was forged on the anvil of the British Empire for the entirely unsentimental reasons of commerce and administration" (Roy 2002: 28). This leads her to question the very Indianness of India: "But even as she was born, she began her struggle against her creators. So is India Indian? It's a tough question. Let's just say that we're an ancient people learning to live in a recent nation"(Roy 2002: 28). Be that as it may, the borders of a nation become all-important concepts which it protects for its own salvation. Herein lies the difference between modern nations and older empires. Twentieth-century state sovereignty is recognized by a "legally demarcated territory. But in the older imaginings, where states were defined by centres, borders were porous and indistinct and sovereignties faded imperceptibly into one another" (Anderson 1983: 26).

Cosmopolitanism or multiculturalism militates against narrow, rigid nationalism and supremacism. As Renato Rosaldo argues, "[i]n contrast with the classic view, which posits culture as a self-contained whole made up of coherent patterns, culture can arguably be conceived as a more porous array of intersections where distinct processes cross from within and beyond its borders" (1992: 20). At the theoretical level, this constitutes the notion of "hybridity" as a synonym for diversity or multiculturality. From the poststructuralist perspective which foregrounds the "constructedness" of culture, culture is a thing learnt, created, and staged. If this be true, then culture is profoundly susceptible to be aped, copied, or appropriated, in a fashion that disrupts the claim that it is the specific property or the unique expression of a single community.

So "hybridity" is not simply a term for the mixing of once separate and self-contained cultural traditions. It also gives credence to the view that culture is an arena of struggle, where self is played off against the "other". Hence for R. Radhakrishnan, hybridity is "transgressive in more than one direction, de-territorializing [...]. With hybridity, anything is possible for the simple reason that hybridity is about making meaning without the repression of a pre-existing normativity or teleology: in the exhilarating a-nomie between 'having been deterritorialized' and 'awaiting to be reterritorialized' there is all manner of unprecedented 'becoming"' (cited in Smith 2004: 252). The discovery that culture can actually flow between national boundaries undermines the modern narrative of nation. "Curiously", argues Ashcroft, "this 
cultural dispersal and heterogeneity has been regarded as more damaging to the narrative of nation than the obvious fact that capital continues to ignore national borders" (2008: 3). The transformation of the global at the level of the local, and the diasporic circulation of local cultures throughout the globe, has subverted the homogeneity of the modern nation state as a repository of culture. With the emergence of the nation as an open cultural site, a transnational site, the global imaginary is characterized by heterogeneity, hybridity, fluidity and movement.

The transnation is much more than "the international" or "the transnational", which is more appropriately conceived as a relation between states. Transnation is neither simply universal, nor simply between or across nations, but is the "embodiment of transformation: the interpolation of the state as the focus of power, the erasure of simple binaries of power, the appropriation of the discourses of power, and the circulation of the struggle between global and local" (Ashcroft 2008: 4). Primarily, it is the fluid, migrating outside of the state that initiates within the nation. "The transnation", asserts Ashcroft, is an "in-between' space, which contains no one definitive people, nation or even community, but is everywhere" (2008: 5). For the eminent Singaporean scholar Rajeev Patke (2002) it is only apt that histories, stories, bodies, and values exist in a space of in-betweenness because it liberates historical objects from the trappings of nostalgia. What this "in-betweenness" indicates is that transnation does not refer to ontology. It is not an object in political space but a mode of talking about subjects in their ordinary lives: "The really difficult thing for human subjects to comprehend, given their entrapment within the discourses of history, nation, race and ethnicity, is that all subjectivity is difference in its differing. It is this that is normal, not the fixity of cultural or national identity, the conviction of one true, shared, essential being" (Ashcroft 2008: 8). This "in-betweenness" signals a liberation which is deeply entrenched in transnational subjectivity, liberation from matters of absence and loss, alienation and not-athomeness. For Bhabha, "the time of liberation is a time of cultural uncertainty, and most crucially, of significatory and representational undecideability" (1994: 35). This representational undecideability subverts a stable system of reference, be it a tradition or a community. This, believes Fanon, is "the zone of occult instability where the people dwell" (1963: 182-3) and is "a veritable theatre of metamorphoses and permutations" (1963: 56) where all "I"s or claims of self have been transcended. This liberation of the human subject from his entrapment within the discourses of history, nation, race and ethnicity culminates in a "world without identity" (Deleuze 1994: 56) where the division between finite and infinite is dissolved. Hence this "zone of occult instability", this "theatre of metamorphoses", this world beyond the closure of identity, is the space of the transnation.

As novelist, Ghosh prioritizes space over time as the structuring principle in narrative. In "The March of the Novel through History", he applauds the novel's ability to eloquently communicate a sense of place and also to interweave the entire spatial continuum from local to global:

The novel as a form has been vigorously international from the start; [...] And yet, the paradox of the novel as a form is that it is founded upon a myth of parochiality, in the exact sense of a parish - a place named and charted, a definite location. [...] Location is thus intrinsic to a novel [...]. (The Imam and the Indian, 294)

Reflecting on "the rhetoric of location" (The Imam and the Indian, 303), Ghosh stresses that he is not thinking merely of place or the physical aspects of the setting. Asserting that the links between India and her diaspora are "lived within the imagination" (The Imam and the Indian, 247), he examines the modes in which "the spaces of India travel with the migrant" to create what Rushdie calls the imaginary homeland:

That is the trouble with an infinitely reproducible space: since it does not refer to actual spaces it cannot be left behind. [...] Eventually the place and the realities that accompany it vanish from 
memory and [...] [t]he place, India, becomes in fact an empty space, mapped purely by words. (The Imam and the Indian, 248-249)

These "words", which signify memories and inherited values, are the "metaphors of space" that constitute "the symbolic spatial structure of India" for the migrant (The Imam and the Indian, 248). Ghosh calls this kind of alternative mapping, in terms of sites of lived experience and memory and not of material location, "the cultural representation of space" (The Imam and the Indian, 250). In Ghosh's fictional realms, local or global, seen or unseen space is perceived and imagined in the narrator's memory as a fundamental facet of individual, national, familial, and communal metamorphoses. In Ghosh's fiction, space is not merely remembered as an imaginative construct but is represented as a domain of political and cultural encounters, encounters which actually shape the connection of different characters with territory and location. Hence, space is represented as a dynamic arrangement between people, places, cultures and societies. James Clifford argues that "space is never ontologically given. It is discursively mapped and corporeally practiced" (1997: 54). According to Clifford, space is composed through movement, produced through use, at the same time an agency and result of action or practice. The construction of space in Ghosh's The Shadow Lines does not simply manifest territorial struggles but serves to show the interplay between local and global influences, national and transnational reconfigurations and above all the search for community and alliances that cut across boundaries of cultural and ethnic identity.

\section{[II]}

Each of Ghosh's novels is concerned with migration and displacement which becomes a "mode of being in the world" (Carter 1992: 101). The task that primarily concerns Ghosh then is "not how to arrive, but how to move, how to identify convergent and divergent movements; and the challenge would be how to locate such events, how to give them a social and historical value" (Carter 1992: 101). The narrator's Hindu family in The Shadow Lines fled from their home in Dhaka to Calcutta during the Partition of India in 1947. During the Second World War they befriend an English family, the Prices, and the series of cultural crossings that the members of the two families are involved in are seamlessly interwoven in the narrative, as are the three major locations in which their lives are lived: Dhaka, Calcutta and London. Far from being moored in a single location, the narrator occupies a discursive space that transcends spatial, political and even temporal boundaries, thereby interrogating essentialist notions of self, community and the nation.

Defining cosmopolitanism as "a stance toward diversity itself," "an orientation, a willingness to engage with the Other", Hannerz (1990: 239) describes cosmopolitans as those who are willing "to become involved with the Other" and are concerned with "achieving competence in cultures which are initially alien" (1990: 240). He further conceptualizes cosmopolitanism both as "an intellectual and aesthetic stance of openness toward divergent cultural experiences," as well as a matter of "competence" of "both a generalized and a more specialized kind" (Hannerz 1990: 239). This competence might be "a state of readiness, a personal ability to make one's way into other cultures, through listening, looking, intuiting and reflecting" (Hannerz 1990: 239).

The narrator's archaeologist uncle Tridib, his alter-ego, endowed with an imagination par excellence, instills in the narrator an obsession with reconstructing lives very different from his own. Tridib teaches the narrator to use his imagination with so much precision that the locations envisioned in the mind "were infinitely more detailed, more precise than anything I would ever see" $(S L, 29)$. Tridib initiates in him a longing to imagine familiar and unfamiliar 
places in memory and imagination. In short, it is Tridib's gift of imagination that kindles in the narrator a desire to travel around the globe. Both have a penchant to study maps to develop and discover their distinct sense of travelling to places without any kind of mental and physical border or barrier. Cultural space can be configured and the unknown can be experienced "concretely" $(S L, 29)$ in the imagination. After all, "a place does not merely exist, $[\ldots]$ it has to be invented in one's imagination" $(S L, 21)$.

Tridib points out places on the Bartholomew's Atlas and also tells him stories about them: "Tridib had given me worlds to travel in and he had given me eyes to see them with" $(S L, 20)$. This gives wings to the narrator's cartographic imagination which leads to the dissolution of spatial boundaries. He once said to the narrator that one could never know anything except through desire "that carried one beyond the limits of one's mind to other times and other places, and even, if one was lucky, to a place where there was no border between oneself and one's image in the mirror" $(S L, 29)$. The range of Tridib's intellectual interests is matched by his fluid personality. To his adda acquaintances, he is anyone from a slum-dweller to an aristocrat. What the narrator likes best in Tridib is his detachment, his "difference" from others. For him, Tridib's stories are a gateway to the world. Thus through generosity the world of the self widens to welcome the dimension of the other; the self's homeland has become a haven for the other, "subjectivity" is presented "as welcoming the Other, as hospitality" (Levinas 1969: 27). Under Tridib's tutelage, the narrator recognizes the contemporaneity of the past, and the lines that demarcate imagination and reality, the self and the other, are blurred.

Although Ghosh represents the world as socially constructed and creates discursive realities to examine the movements of power, he endeavours to find a way of escaping the realm of discourse controlled by the hegemonic Western mode of knowledge production and its ways of narrating the world. One possibility for circumventing this powerful and deeply rooted way of knowing is to constitute transcendent, ethical realities that cannot be accessed through a specific language and discourse. Therefore, in meeting the other, we should try to remain open and responsive to it, rather than immediately attempting to define it from our own starting points. Alterity, meaning the unknowable and unreachable nature of the other, cannot be attained, but it can, and must, be approached.

In Levinas's view, this ethical approaching of the other's alterity is our responsibility. The means by which this can be achieved include the use of a kind of imaginative empathy and reciprocity in the encounter with the other. Radhakrishan has examined these concerns as they appear in relation to the concepts of imagination and space in Ghosh. These same concerns are relevant in the context of all Ghosh's novels, and his writing in general. Space in Ghosh's narratives is manifested as a many-faceted problematic that brings together time, place (imaginary and real dimensions), location (whether geographical or discursive) and identity (both personal and national/ communal/collective). Tridib, the inspired lover, seems to have chosen to live the story of Tristan, a story that cannot be plotted on any map. The story defies any spatial and temporal specificities:

It happened everywhere [...]It was an old story, the best story in Europe, Snipe said, told when Europe was a better place, a place without borders and countries - it was a German story in what we call Germany, Nordic in the north, French in France, Welsh in Wales, Corn in Cornwall ... $(S L, 186)$

Tristan's is a very sad story about a man "without a country, who fell in love with a woman-across-the-seas" (SL, 186). The romance of Tridib-Tristan finds its consummate object in May. In his fourth letter to May, Tridib gives an elaborate, pornographic account of the sexual love of two strangers in a bombed-out theatre in war-time London. He rams home the point that that is how he desires to meet May, "as a stranger in a ruin": "as the completest 
of strangers - strangers across the seas - all the more strangers because they knew each other completely" (SL, 144). What is more he wants to meet her in a place "without a past, without history, free, really free, two people coming together with the utter freedom of strangers" ( $S L$, 144). Like Tristan who is a man without a country, Tridib's imagination enables him to think beyond the boundaries of cultures and nations, time and space. Hence, his craving for an ahistorical meeting place. He longs for a transcendental state outside ordinary human experience, beyond the realm of distinctions where opposites cancel each other out. Tridib's passion becomes an analogue of ecstasy whose power dissolves the world, so that "'the others' cease to be present; and there are no longer either neighbours or duties, or binding ties, or earth or sky; one is alone with all that one loves. 'We have lost the world and the world us"" (Rougemont 1962: 146). Such is the nature of this ecstasy.

In Radhakrishnan's view, these basic insights involving the use of a certain kind of ethical imagination in the envisioning of interhuman and interdiscursive relationships amount to a newness in and of the imagination: "If only the world could be imagined that way! - new and emergent perceptions of nearness and distance; long denied and repressed affirmations of solidarities and fellow-heartedness in transgression of dominant relationships and axes of power; new and emergent identifications and recognitions in profound alienation from canonical-dominant mystifications and fixations of identity" (Radhakrishnan 2003: viii). Ghosh's narrator compels the reader to imagine space above the narrow confines of a singular culture, nation, territory and community. Inhabiting a world of human, geographical and political barriers, the narrator and Tridib have a vision: to construct a free space (in a world without binaries) which is supposed to be above all temporal or spatial constraints. This contentious space is a transcultural space - a space of cultural and ethnic transactions where characters seek to overthrow artificial frontiers to come to terms with the reality of cultural and political transformations. Moreover, transcultural spaces also refer to cross-cultural practices of imagining or remembering space and place in the novel. While going down memory lane, the narrator tries to inhabit a transcultural space like Tridib to achieve freedom and liberty in its entirety since freedom is central to every character's story in the novel. It is indeed ironic that Tridib, who desires absolute freedom, who like an artist creates his own world in order to be free of others' inventions, who transcends arbitrary borders and distinctions and hatreds in search of a truer sense of commonality, finds himself entangled in communal riots. May once abused Tridib as an incompetent person: "All you're good for is words. Can't you ever do anything?" (SL, 173). The same Tridib, urged by May, heroically steps out of the car in Dhaka to rescue the nonagenarian and is slaughtered by a frenzied mob puffed up by militant nationalism and communalism.

The cosmopolitan Tridib is a modern nomad who transcends with ease different geographical spaces. If Tridib is the narrator's mentor, however, Ila is the narrator's antithesis. Like Tridib, Ila is the child of a diplomat, a world traveller. But she is the obverse of an imaginative traveler; her consciousness is the product of a "worldwide string of departure lounges" $(S L, 21)$. She might have travelled all across the globe, but she is so insular that "although she had lived in many places, she had never travelled at all" $(S L, 21)$. The places went past her in an "illusory whirl of movement" $(S L, 23)$. On the contrary, the narrator passionately believes that "a place does not merely exist, that it has to be invented in one's imagination" $(S L, 21)$. In stark contrast to Hannerz's concept of the cosmopolitan, Ila is a perfect example of Bauman's (1997) tourists who "perform the feat of not belonging to the place they might be visiting; theirs is the miracle of being in and out of place at the same time" and the "point of tourist life is to be on the move, not to arrive" (Bauman 1997: 89). Since the tourists "embark on their travels by choice," their decision to leave home to explore foreign parts is "all the easier to make for the comforting feeling that one can always return, if 
need be" (Bauman 1997: 91). Ila's presentism blunts her vision and cramps her to make any inter-cultural negotiations. What she remembers are excitements triggered by the "shifting landscapes of her childhood" (SL, 20). This explains the lack of concreteness of her imagination. For Ila "the current was the real: it was as though she lived in a present which was like an airlock in a canal, shut away from the tidewaters of the past and the future by steel floodgates" $(S L, 30)$. Ila has no sense of identity and continuity with the past. The temporal perspective in her life has become so foreshortened that she lives in a perpetual present, not the experiential, qualitative co-presence of all the elements constituting the past recaptured by memory. Her peripatetic lifestyle has enlarged her mastery over physical space but has also confined her "increasingly to the mental and emotional space of the momentary present devoid of continuity and significant relations with past and future" (Meyerhoff 1955: 111). Hence, Ila's dimension of mental "space" has contracted to the fragmentary moment of the present.

While Ila aspires to be a free spirit with scant regard for territorial and cultural frontiers, Thamma is an advocate of exclusivist nationalism. Thamma was a college student when terrorist outfits like "Anushilan Samiti" and "Jugantar" recruited youngsters as their cadres. She tells the child narrator the incident of how one of her classmates was arrested by the police. A shy, quiet, bearded boy, the young patriot seemed an unlikely terrorist but he showed great resolve. His impassive face and "clear, direct and challenging" gaze was fixed on the policeman. Inspired by the patriotism of Bagha Jatin and Khudiram Bose, Thamma wanted to do something for the terrorists. She mused that "if only she had known, if only she had been working with him, she would have warned him somehow, she would have saved him, she would have gone to Khulna with him too, and stood at his side, with a pistol in her hands, waiting for the English magistrate" $(S L, 39)$. Wholly committed to the nationalist ideal of independent India, Thamma would have done anything to be free from colonial oppression.

Born in Dhaka, Thamma migrated to Mandalay because of her husband's profession. After her husband's death, she joined a school in Calcutta as a teacher. This provided her with a stability in her rootless existence. While in Moulmein and Mandalay she lived in "a succession of railway colonies" $(S L, 124)$ and her life became uneventful. To her "nothing else in that enchanted pagoda-land had seemed real enough to remember $(S L, 124)$ apart from hospitals, railway stations and Bengali Societies. Interestingly, in this she resembles her opposite, Ila, whose peripatetic lifestyle forbids her to attach herself to any place. The bloodshed of the Partition severs Thamma's connection with her ancestral home in Dhaka. However, a chance meeting with one of her kin makes her know that her nonagenarian Jethamoshai still lives in their house at Jindabahar Lane in Dhaka. What is more, she is horrified to learn that their whole house has been occupied by Muslim refugees from India. Throughout her life Thamma never displayed much family feeling. In fact, "she was extremely wary of her relatives; to her they represented an imprisoning wall of suspicion and obligations" $(S L, 129)$. However, consanguinity propels her to dismantle this "imaginary barrier" $(S L, 129)$ and she decides to travel to Dhaka to bring her Jethamoshai back to Calcutta.

Thamma's journey to Dhaka, her birthplace, initiates her education in the artificiality of the nationalist construct. Her neat and orderly mind seems to be in a quandary when she tries to solve the puzzle "how her place of birth had come to be so messily at odds with her nationality" (SL, 152). Thamma has a hard time coming to terms with the technicalities of passports and visas and the politics of international borders. For her, traveling to Dhaka was different in the pre-Partition era when she could "come home to Dhaka" $(S L, 152)$ whenever she wanted. The fact that her journey to Dhaka is not only physical but also epistemological when the young narrator teases Thamma out of her thoughts: "How could you have 'come' 
home to Dhaka? You don't know the difference between coming and going" (SL, 152)! Years later the mature narrator realizes that his grandmother's journey not only destabilizes her fixed conceptions of "home" but also exposes the faults of a language system:

Every language assumes a centrality, a fixed and settled point to go away from and come back to, and what my grandmother was looking for was a word for a journey which was not a coming or a going at all; a journey that was a search for precisely that fixed point which permits the proper use of verbs of movement" $(S L, 152)$.

Thamma's conceptions of home as a place of stability and coherence thus shattered, she receives a further setback when her son exposes the limits of her exclusionary nationalism. Her naïve belief in the existence of borders corresponds with Anderson's conceptualization of the nation as "limited" with "finite, if elastic boundaries, beyond which lie other nations" (1983: 16). When she expresses her curiosity to see the border between India and East Pakistan from the plane, her son humorously asks her whether she thought that the "border was a long black line with green on one side and scarlet on the other, like it was in a school atlas" (SL,151). When she learns that neither trenches nor soldiers with guns pointing at each other separate the two countries but there are only green fields with no distinct demarcation zones, she discovers the limits of her brand of nationalism:

But if there aren't any trenches or anything, how are people to know? I mean, where's the difference then? And if there's no difference both sides will be the same; it'll be just like it used to be before, when we used to catch a train in Dhaka and get off in Calcutta the next day without anybody stopping us. What was it all for then - partition and all the killing and everything - if thereisn't something in between? $(S L, 151)$

The modern political border, as her son explains to her, doesn't exist on the frontier but in the airport. One crosses it when he fills in the disembarkation cards and the forms demanding one's nationality, etc. This aspect of international boundaries determines the limits of a sovereign authority. Thoroughly unaware about contemporary international travel regulations, Thamma, the old guard nationalist who once dreamt of a new nation, "believed in the reality of nations and borders" beyond which "existed another reality" ( $S L, 219)$. The only relationship that existed "between those separate realities was war or friendship" $(S L, 219)$. The partitioning of the Bose family house in Dhaka is itself an allegory for Thamma's self/other conceptualization. Whatever exists beyond the other side of the partitioning wall is an inverted image of theirs which is the epitome of normalcy. The upside-down world seems to be a safe place to escape to when problems surface on their own side. The unseen, unknown other part of the house is a source of immense interest for Thamma and Mayadebi and the "strange thing was that as we grew older even I almost came to believe in our story" $(S L, 126)$. This self-other dialectic permeates Thamma's conceptions of nation and nationalism. By imagining the community of the nation, Thamma is certainly not, in Ila's words a "fascist", but as Tridib sums it up "only a modern middle-class woman" (SL,78).

The patterned orderliness and stability that Thamma seeks is dismantled when she lands in Dhaka airport. The first question she is prompted to ask, confounded by her present surroundings, is "Where's Dhaka? I can't see Dhaka" $(S L, 193)$. Thamma's Dhaka is confined in the localized surroundings of her ancestral home in Jindabahar Lane which had "long since vanished in the past" (SL, 193). This past/present disjuncture leads to her confusion. Her quest for the idyllic, pre-Partitioned Dhaka of her childhood is projected as a nostalgic return home. Throughout her life Thamma has contemptuously dismissed nostalgia as a "weakness, a waste of time, that it is everyone's duty to forger the past and look ahead and get on with building the future" (SL, 208). Compelled by circumstances, she now realizes the gravity of her predicament that she has "no home but in memory" $(S L, 194)$. Thamma's Indian citizenship now confronts her with her strong loyalties and affiliations to the solidarity of her ancestral home. Her alienation from her homeland is pointed out to her by Tridib's teasing remark: 
"But you are a foreigner now, you're as foreign here as May - much more than May, for look at her, she doesn't even need a visa to come here" $(S L, 195)$. Nevertheless, Thamma perceives her visit to Jindabahar Lane as her "homecoming". Dressed in a white sari with a red border she is "going home as a widow for the first time" $(S L, 205)$. After meeting Jethamoshai she emotionally declares that they have "come home at last" $(S L, 212)$. The contradiction between Thamma's going and coming, home and abroad, local and national identities, surfaces in her resolution to bring her Jethamoshai to "where he belonged, to her invented country" ( $S L$, 137). Thamma's glorification of the myth of the nation is punctured by her senile Jethamoshai's stubborn refusal to migrate:

I don't believe in this India-Shindia. It's all very well, you're going away now, but suppose when you get there they decide to draw another line somewhere? What will you do then? Where will you move to? No one will have you anywhere. As for me, I was born here, and I'll die here. (SL, 215)

Thamma's "home" turns unhomely when the car in which she was returning along with Jethamoshai in a rickshaw is attacked by some frenzied rioters. Tridib rushes out to save the old man but both of them are brutally killed along with the rickshaw-puller Khalil. Thamma's ancestral birthplace is also the city of the fanatic rioters which now is transformed into the split space of home/not-home. Tridib's violent death instills in her a hatred for "them". Hence, when war breaks out with Pakistan in 1965, she donates her gold chain, her late husband's reminiscence, to the war fund: "For your sake; for your freedom. We have to kill them before they kill us; we have to wipe them out" ( $S L, 237)$. She takes solace from the fact that it's not a street ambush but an organized war "with tanks and guns and bombs" (SL, 237). Throughout the novel Thamma remains an exponent of territorial nationalism and also learning its hard lessons.

Temporal simultaneity is complemented by identical spatial realities across the "lookingglass border" (SL, 233). London and Berlin, just before World War II are mirror images of each other with the same "exhilaration in the air" $(S L, 66)$. Travelling between the two capitals Alan Tresawsen, May's uncle and Tridib's hero, felt that he was "stepping through a looking-glass" (SL, 66). Calcutta and Dhaka serve as mirror images of each other during the riots in 1964. The communal frenzy of "Hindu Calcutta' and "Muslim Dhaka" resembles "the war between oneself and one's image in the mirror" (SL, 204). The adult narrator, after making a series of connections listening to others' perceptions and experiences, realizes that he and Tridib were in the same predicament in two different cities: "I, in Calcutta, had only to look into the mirror to be in Dhaka; a moment when each city was the inverted image of the other" $(S L, 233)$. The narrator who as a child believed in the reality of nations and space, "that distance separates, that it is a corporeal substance...that across the border there existed another reality" $(S L, 219)$, has at the end of the narrative these ideas shattered. The borders between nations in his Bartholomew's Atlas turn into glass, the compartmentalized world turns composite. As he tries to "learn the meaning of distance", he perceives "that within the tidy ordering of Euclidean space, Chiang Mai in Thailand was much nearer Calcutta than Delhi is; that Chengdu in China is nearer than Srinagar is" $(S L, 232)$. The narrator thus interrogates the principles of temporal and spatial division. As he acknowledges, he has created his own secret map of the world, - "a map of which only I knew the keys and coordinates, but which was not for that reason any more imaginary than the code of a safe is to a banker" (SL, 194). This map of the world is one response to Radhakrishnan's call for postmodern spaces that are imagined "in excess of and in advance of [...] actual history in the name of experiences that are real but lacking in legitimacy" (Radhakrishnan 2003: 61). The representation of London in the novel consists of several levels: the past is represented through an amalgamation of official history and personal imagination, and the present through maps and eye-sight. Radhakrishnan continues: "each of these [...] realities must imagine its 
own discursive-epistemic space as a form of openness to one another's persuasion" (2003: 61 ). What has to be avoided is the situation where one version speaks for all, or where all the versions are "islands unto themselves" (Radhakrishnan 2003: 61).

The narrator's belief in the absoluteness of cartographic divisions thus shattered, he learns that the separatist logic of frontiers cannot enforce cultural difference. Ironically, what establishes the identical nature of realities on both sides of the border between India and Pakistan is mutually self-destructive violence. The sacred relic known as the Mui-i-Mubarak disappears in Srinagar and riots break out in Calcutta and Dhaka. The administrators who drew the boundaries between India and Pakistan believed in the "enchantment of lines, hoping perhaps that once they had erected their borders upon the map, the two bits of land would sail away from each other like the shifting tectonic plates of the prehistoric Gondwanaland" (SL, 233). The narrator discerns a profound "yet-undiscovered irony" in the political separation:

the simple fact that there had never been a moment in the four-thousand-year-old history of that map, when the places we know as Dhaka and Calcutta were more closely bound to each other than after they had drawn their lives - so closely that I, in Calcutta, had only to look into the mirror to be in Dhaka; a moment when each city was the inverted image of the other, locked into an irreversible symmetry by the line that was to set us free - our looking-glass border. $(S L, 233)$

Paradoxically, the communal riot indicates the deep emotional involvement of the Hindus and the Muslims alike.

Sudhir Kakar, in his influential book The Colours of Violence: Cultural Identities, Religion and Conflict (1996), distinguishes between pre-colonial "religious" conflicts and post-colonial "communal" violence in the Indian sub-continent. While religion is "a matter of personal faith and reverence for a particular set of icons, rituals, and dogmas", asserts Kakar, communalism entails one's "exclusive attachment to his or her community combined with an active hostility against other communities which share its geographical and political space" (1996: 13). The overarching identities as "Muslim" and "Hindu" were highly charged by the divisiveness of the Partition of 1947, "the most momentous event in the shaping of Hindu-Muslim relations in independent India" (Kakar 1996: 37). The bitter animosity between these two communities is an off-shoot of the British imperialist policy of divide and rule by playing off one against the other. The presentation of the post-Partition riots in Calcutta expatiates Kakar's observations. The young narrator's school-bus is more than half-empty as the majority of the students are confined at home because trouble is apprehended in Calcutta. Rumour spreads that "they" have poisoned Calcutta's water supply. This incident echoes the rumours in wartime London that German aeroplanes were dropping toffee-tins "to demoralize the population by getting at the children" $(S L, 184)$. In the narrator's account the children "huddled together" $(S L, 189)$ in the bus immediately comprehend that the vague identification "they" refers to the Muslims. The "us" and "them" binarism is crystallized when their own friend Montu is perceived as an "other" because he is a Muslim. When the adult narrator recalls the incident he reflects on the extent to which children had internalized this self/other split:

I remember we did not ask him any questions - not who 'they' were, nor why 'they' had poisoned their own water. We did not need to ask any questions; we knew the answers the moment he had said it: it was a reality that existed only in the saying, so when you heard it said, it did not matter whether you believed it or not - it only mattered that it had been said at all. (SL, 199-200)

The riots transform the city. The frightening sound of voices alternate with random moments of silence to produce "the authentic sound of chaos" $(S L, 201)$. When the children return home their well-known streets seem completely unfamiliar. Even the positioning of a rickshaw at a street-corner expresses a threat: "had it been put there to keep Muslims in or Hindus out? At that moment we could read the disarrangement of our universe in the perfectly ordinary angle of an abandoned rickshaw" $(S L, 203)$. The contention that riots are exceptional 
to South Asia is repeated in Ghosh's In An Antique Land. Not to speak of communal tensions, micronationalist factions subvert the myth of the homogeneity of the Indian nation-state. Robi reflects on how terrorist and separatist outfits in Assam, the north-east, Punjab, Sri Lanka, Tripura utter the rhetoric of freedom to fragment the nation: "And then I think to myself, why don't they draw thousands of little lines through the whole subcontinent and give every place a new name? What would it change? It's a mirage; the whole thing is a mirage. How can anyone divide a memory? ( $S L, 247)$. Territorial space can be demarcated by lines but the collective unconscious remains indivisible.

However, the separatist strategies of the politics of national boundaries epitomized by the Partition fail to suppress syncretic possibilities. The ecumenical Hazratbal shrine is revered by Muslims, Hindus, Sikhs and Buddhists alike that challenges the "Christian sense of the necessity of quarantine between doctrines". The synthesizing quality of the shrine is stressed when the theft of the relic brings about "a spontaneous show of collective grief". Maulana Masoodi. "an authentic hero, forgotten and unsung today as any purveyor of sanity" (SL, 225226), unites the various Kashmiri communities in their demonstrations. When the relic is recovered, Kashmiris erupt in joy. However, this exemplary secular tolerance and cultural syncretism is marred by a violent riot in distant Khulna. But "As always, there were innumerable cases of Muslims in East Pakistan giving shelter to Hindus, often at the cost of their own lives, and equally in India, of Hindus sheltering Muslims" (SL, 229-230). Unfortunately, no Martyrs Memorials were erected for these unsung ordinary people. Just as the partition of the Bose family in Dhanmundi fail to prevent relatives from being involved with each other, so also the arbitrary division of the country fails to slice one community apart from the other. Amitav Ghosh experienced a similar situation after riots broke out in Delhi in November, 1984 after the assassination of Indira Gandhi. What he remembers is not only "the horror of violence" but also "the affirmation of humanity...the risks that perfectly ordinary people are willing to take for one another" (The Imam and the Indian, 61). Such people demonstrate "the indivisible sanity that binds people to each other independently of their governments" (SL, 230). Eventually, The Shadow Lines "became a book not about any one event but about the meaning of such events and their effects on the individuals who live through them" (The Imam and the Indian, 60). Jethamoshai, the lone, left-behind member of his family, is looked after by a Muslim rickshaw-puller Khalil. His children look up to the old man as their grandfather. Theirs is a family based not on kinship but on love and solidarity, the very basis of community formation. Ghosh's stance on inter-community solidarity and his assertion of humanity exposes the parochialism of nationalism. The dangerous potential for violence and aggression in the creation of exclusivist collective identities is cogently explained by Regina Schwartz: "Imaginary identity as an act of distinguishing and separating from others, of boundary making and line drawing, is the most fundamental act of violence we commit" (2000: 187). Celebrating "the complex web of relationships between people that cut across nations and generations", The Shadow Lines thus becomes, believes Robert Dixon, "a fictional critique of classical anthropology's model of discrete cultures and the associated ideology of nationalism"(2003: 20).

In Ghosh, the male protagonists are rationalists/idealists. Conversely, the female protagonists are pragmatists/humanists. They are more successful than their male counterparts because they are more in touch with life's reality. May occupies a distinctive position in Ghosh's gallery of women characters which include Zindi in The Circle of Reason, Dolly in The Glass Palace, Nilima in The Hungry Tide. As an integrated being, May is a champion of humanity. She tirelessly collects funds in London streets for providing housing to the earthquake victims in Central America. In Raibajar, she dismisses the narrator's grandfather's huge imported wooden table as "utterly useless", as a "worthless bit of England" $(S L, 49)$. She 
indignantly remarks that the amount of money squandered on the table would have provided shelter for a lot of people. She displays courage and compassion in killing the dying dog in Calcutta in order to spare it from more pain. But the defining moment in May's humanism comes in the narrow Jindabahar Lane when the hostile rioters set upon the old man and his rickshaw-puller. While Thamma, the old man's blood relation, wants her driver to drive away, the determined May jumps out of the car to defend them: "Your grandmother screamed at me. She said I didn't know what I was doing, and I'll get everyone killed. I didn't listen; I was a heroine" $(S L, 250)$. But in the fiasco, Tridib is killed. For seventeen years after the incident May holds herself responsible for Tridib's death. She never felt insecure in the mob because "they wouldn't have touched me, an English memsahib" $(S L, 251)$ but not Tridib. She finally realizes that Tridib "gave himself up; it was a sacrifice" (SL, 251-252). If her self asserted itself in Dhaka - "I was a heroine" $(S L, 250)$ - after the incident she becomes selfless. She is committed to her altruistic mission, a commitment which even intrudes into the private spaces of her domestic life as she sleeps on the floor: "After all, this is how most people in the world sleep. I merely thought I'd throw in my lot with the majority" $(S L, 158)$. While Tridib's death hardens Thamma's rigid binarism of "us" and "them", May's attitude towards life becomes transnational as she tries to fuse the Self/Other dialectic. Her rhetoric of communitarianism is based on an "understanding of subjectivity, one that values mutual dependency, reliance, appreciation, and trust between the Self and the Other" (Lin, 11). This indeed is a "paradigmatic reconsideration of the status of the Other in our understanding of who we are our self, identity, and individuality" (Lin, 1). The self"s being "with" the other is an integral part of the ethical relationship with the other. This 'withness', conceptualizes Margaret Chatterjee, "covers up the essential difference that there is between people, although we are endowed with the capacity of bridging that distance by embarking on the project of being 'towards' the other" (1963: 220). This fusion reaches its zenith in May's sexual union with the narrator. May and the narrator meet as free citizens transcending the divisions of colonizer/colonized, white/non-white, self/other. Through his union with May, which melts all boundaries, the narrator is granted "the glimpse of... a final redemptive mystery" $(S L, 252)$, the mystery of the depths of human experience.

Literary narrative provides a new perspective of looking at the historical past, often questioning the credibility of the historical representation. By way of questioning what Hayden White calls history's tropic prefiguration, the prominence given to key historical figures, the erasure of subaltern individuals or communities, literature foregrounds the role of narrative in constructing one's understanding of the world and meaning and truth. A postcolonial writer, in his/her critical re-interpretation of the historical archive, creates a hybrid text that combines historical evidences and imaginative reconstructions, historical as well as invented characters. With this interplay, history is stripped of its objective quality. That literary texts have been widely recognized as essential materials for historical study is evident in Spivak's endorsement of Foucault's suggestion that "to make visible the unseen can also mean a change of level, addressing oneself to a layer of material which hitherto had no pertinence for history and which had not been recognized as having any moral, aesthetic or historical value" (Spivak 1995: 27-28). Evidently what Ghosh tries to reconcile are the "analytical" histories utilizing the rational categories of modern historical thought and the "affective" histories which account for the plural ways of being-in-the-world. After all, as E.L. Doctorow observes, the modes of historical and fictional narratives mediate "the world for the purpose of introducing meaning" (cited in Hutcheon 1988: 112). 


\section{References}

Anderson, Benedict. 1983. Imagined Communities: Reflections on the Origin and Spread of Nationalism. London: Verso.

Ashcroft, Bill. 2002 [1989]. The Empire Writes Back. London and New York: Routledge.

- 2008. "Globalization, the Transnation and Utopia" In: Krishna Sen and Sudeshna Chakravarti (eds.) Narrating the (Trans)Nation: The Dialectics of Culture and Identity. Kolkata: Dasgupta \& Co., 1-24.

Bauman, Zygmunt. 1997. Postmodernism and Its Discontents. Cambridge: Polity Press.

Bhabha, Homi K. 1994. The Location of Culture. London and New York: Routledge.

Carter, Paul. 1992. Living in a New Country: History, Travelling and Language. London: Faber and Faber.

Chatterjee, Margaret. 1963. Our Knowledge of Other Selves. New Delhi: Asia Publishing House.

Clifford, James. 1997. Routes: Travel and Translation in the Late Twentieth Century. Cambridge: Harvard UP.

Daiya, Kavita. 2003. “No Home But in Memory': Migrant Bodies and Belongings, Globalization and Nationalism in Amitav Ghosh's Novels" In: Brinda Bose (ed.) Amitav Ghosh: Critical Essays. Delhi: Pencraft International, 36-55.

Deleuze, Gilles and Felix Guattari. 1994. What is Philosophy. Trans. H. Tomlinson and G. Burchell. New York: Columbia UP.

Dixon, Robert. 2003. “"Travelling in the West': The Writing of Amitav Ghosh" In: Tabish Khair (ed.) Amitav Ghosh: A Critical Companion. New Delhi: Permanent Black, 9-35.

Fanon, Frantz. 1963. The Wretched of the Earth. New York: Grove Press.

Ghosh, Amitav. 1995 [1988]. The Shadow Lines. Rpt. New Delhi: OUP.

— 2000. "The Shadow Script”, Interview. New Delhi: First City, Sept. 2000.

- 2002. The Imam and the Indian: Prose Pieces. New Delhi: Ravi Dayal Publisher.

Hannerz, Ulf. 1990. "Cosmopolitans and Locals in World Culture", Theory, Culture and Society 7 (1990), 237-52.

Hutcheon, Linda. 1988. A Poetics of Postmodernism. London: Routledge.

Kakar, Sudhir. 1996. The Colours of Violence: Cultural Identities, Religion and Conflict. Chicago: University of Chicago Press.

Kaviraj, Sudipta. 1992. “The Imaginary Institution of India.” Subaltern Studies VII: Writings on South Asian History and Society. Ed. Partha Chatterjee and Gyanendra Pandey. New Delhi: Oxford University Press, 1-39.

Levinas, Emmanuel. 1969. Totality and Infinity: An Essay on Exteriority. Trans. Alphonso Lingis. Pittsburgh: Duquesne Up.

Lin, Lidan. 1998. The Rhetoric of Posthumanism in Four Twentieth Century International Novels. Diss., University of North Texas, Ann Arbor: UMI.

Meyerhoff, Hans. 1955. Time in Literature. Berkeley: University of California Press. 
Nandy, Ashis. 1983. The Intimate Enemy: Loss and Recovery of Self under Colonialism. New Delhi: Oxford University Press.

Patke, Rajeev. 2002. "To Frame a City: the Singaporean Poet in the Postmodern City" In: W. Lim (ed.) Postmodern Singapore. Singapore: Select Books, 106-117.

Radhakrishnan, R. 2003. Theory in an Uneven World. Oxford: Blackwell.

Rosaldo, Renato. 1992. Culture and Truth: The Remaking of Social Analysis. Boston: Beacon Press.

Rougemont, Denis de. 1962. Passion and Society. Trans. Montgomey Belgion. London: Faber and Faber.

Roy, Arundhati. 2002. The Algebra of Infinite Justice. New Delhi: Penguin Books.

Schwartz, Regina. Cited in Manfred Steger 2000, Gandhi's Dilemma: Nonviolent Principles and Nationalist Power. New York: St. Martins Press.

Smith, Andrew. 2004. "Migrancy, hybridity, and postcolonial literary studies." The Cambridge Companion to Postcolonial Literary Studies. Ed. Neil Lazarus. Cambridge: Cambridge University Press, 241-261.

Spivak, Gayatri Chakravorty. 1995. "Can the Subaltern Speak?” In: The Post-colonial Studies Reader. Ed. Bill Ashcroft, Gareth Griffiths, Helen Tiffin. Routledge: London and New York, 24-28. 